\title{
Positive Mental Health Model Based on Authentic Leadership and Elements of Socialization
}

\author{
José Luis Calderón-Mafud1*, Manuel Pando Moreno², Cecilia Colunga-Rodríguez ${ }^{3}$, \\ Ma. de Lourdes Preciado-Serrano ${ }^{1}$ \\ ${ }^{1}$ Universidad de Colima, Colima, México \\ ${ }^{2}$ Universidad de Guadalajara, Guadalajara, México \\ ${ }^{3}$ Instituto Mexicano del Seguro Social, Universidad de Guadalajara, Guadalajara, México \\ Email: *joseluis.calderonmafud@gmail.com, Manolop777@yahoo.com.mx, ccolungar@yahoo.com, malourdespre@gmail.com
}

How to cite this paper: Calderón-Mafud, J. L., Moreno, M. P., Colunga-Rodríguez, C., \& de Lourdes Preciado-Serrano, M. (2018). Positive Mental Health Model Based on Authentic Leadership and Elements of Socialization. Psychology, 9, 588-607.

https://doi.org/10.4236/psych.2018.94037

Received: February 3, 2018

Accepted: April 9, 2018

Published: April 12, 2018

Copyright $\odot 2018$ by authors and Scientific Research Publishing Inc. This work is licensed under the Creative Commons Attribution International License (CC BY 4.0).

http://creativecommons.org/licenses/by/4.0/

\begin{abstract}
In this document, we propose a theoretical model of occupational positive mental health that relates it to elements of organizational socialization (formation and coworkers support) and characteristics of authentic leadership (transparency in relationships, balanced processing and internalized morality), generating in the workers first, the improvement of the interpersonal relations in the work and the development of the strengths in the work, and these facilitate the empowerment in the tasks when combined with elements of socialization, generating personal well-being and allowing to form in the workers a philosophy of working life. In general, it is proposed that it is based on education and learning, which seeks to facilitate an adaptation to the organization with perceptions of equity, and to develop positive mental health at work and its subsequent benefits. This model is proposed with the purpose of developing empirical tests that verify their relationships. The positive results could serve as a basis for interventions and develop new lines of research for the future of these fields of study.
\end{abstract}

\section{Keywords}

Occupational Positive Mental Health, Authentic Leadership, Elements of Socialization, Wellbeing, Organizations

\section{Introduction}

The scope of work and its effects on human life have been studied by different disciplines, including organizational psychology, because work today is strongly 
linked to organizations, their processes and structures, which gives them complexity and generates effects on people, their families and society in general (Hall, 1996).

Currently, changes in trade agreements and, in general, in the economies of countries, have an impact on modes of production, introduce modern technologies and standards, induce people to constantly change their employer or organization and set conditions of uncertainty that limit your chances of obtaining well-being at work and in your personal life.

Health in the organizational field has been studied for decades, however, that has not made the issue of mental health the priority for organizations, so promoting positive mental health and wellbeing effects to create productive environments and harmonious continues to be a challenge for organizations under the premises of sustainability and social responsibility that guide the standards and values of most organizations.

To address positive mental health in current organizations, it should be known that such organizations promote their culture through socialization and resources such as leadership that function as models for newcomers or minor hierarchies, where programs training and understanding, are combined with the social support received to increase their perspectives of future. It is known that the OS has strong relationships with job satisfaction, organizational commitment and work engagement, however, the role of leadership has only been addressed tangentially and it is possible that when added has a significant impact on positive health variables and not only in occupational terms.

In short, this article seeks to show through a theoretical model how currently the growing need for socialization generates impacts on positive mental health of workers and the leadership it is probably a fundamental socialization resource through which can be detonated explanation and intervention phenomena related to growth, innovation and well-being of individuals.

\section{Socialization and Labor Resources}

In the current context of organizational behavior research, there are growing efforts to develop a positive vision, based on the resources and strengths of people that result in wellbeing and optimal functioning. Among the variables that are currently most widely studied are the psychological capital, work engagement and more related to optimal performance in organizations and with the results of positive socialization (Saks \& Gruman, 2011; Salanova, Agut, \& Peiró, 2005). However, many of the organizational efforts are geared as Zak (2017) mentions them "golden handcuffs" to employees by providing benefits such as free meals, massages at work and others, when the company better.

According to the model Demands-Resources (Demerouti, Bakker, Nachreiner, \& Schaufeli, 2001; Bakker \& Demerouti, 2007; Bakker \& Demerouti, 2013), it is possible to perceive the organization dividing the environment Demands of work, that is, physical, psychological, social or organizational factors typical of a 
job that require the worker's physical and psychological effort, as they appear in situations of work overload, job insecurity, and role ambiguity. And, on the other hand, Work Resources, which are understood as the physical, psychological, social or organizational integrity of a job that serves to achieve work goals, reduce the demands of work, in addition to stimulating personal growth, learning and the development.

These labor resources can come from the organization, relationships, work organization, and self-task (Bakker \& Demerouti, 2007) and can be considered as psychosocial factors from the point of view of health at work (Aranda-Beltrán, Pando-Moreno, Torres-López, Salazar-Estrada, \& Franco-Chávez, 2005). It is known to be primarily related to the motivational potential, organizational commitment, performance extra-role and job satisfaction because they facilitate growth, learning and development, and all of them are in the process of organizational socialization is defined as the process to acquire knowledge about organization and work, through which an individual goes from being an external member to identify with values, develop skills and in short assume an organizational function and participate as a member of the organization successfully (Louis, 1980; Haueter, Macan, \& Winter, 2003).

\section{Organizational Socialization and Leadership}

Effective socialization helps workers overcome potential negative aspects typical of adapting to a new job, such as stress, anxiety and uncertainty in the face of the new situation and the new task (Taormina, 1997; Nelson \& Quick, 1991; Saks, 1996; Wanous, 1992). This process is also one of the main ways in which the culture of an organization is maintained and can have a lasting effect on confidence, attitudes and behaviors of employees (Ashforth, Sluss, \& Harrison, 2007; Bauer, Morrison, \& Callister, 1998; Zak, 2011; Zak, 2017).

The models by Chao, O'Leary-Kelly, Wolf, Klein and Gardner (1994), Cooper-Thomas and Anderson (2006) and Taormina $(1994,1997)$ have shown compatibility and some consensus on how learning and social colleagues work to generate understanding of work, role and organization by interacting with each other, developing efficiency, satisfaction and emotional support (Chao et al., 1994; Taormina, 1994, 1997, 2004) and not only information and content (Rollag, Parise, \& Cross, 2005).

The process of organizational socialization does not always work properly, and individuals can go through states of uncertainty, where lack of cultural clarity and absence of rules and regulations are replaced by personal criteria that facilitate confusion and lack of learning resources (Allen \& Meyer, 1990; Allen, 2006).

And, on the other hand, it is likely that organizations seek to impose excessively the culture and values to its members, for the sake of productivity, limiting autonomy and wellbeing in general (Michaels, Cron, Dubinsky, \& Joachimsthaler, 1988; Sarros, Tanewski, Winter, Santora, \& Densten, 2002). This could mean 
that this process studied in isolation would suggest that is positive, however, it must be bounded by estimating personal development, to avoid bias induced alienation where the pressure to suit any cost to the organizational culture, limit Positive Mental Health in employees.

To address the OS from a positive point of view, Saks and Gruman (2011) mentioned a new approach to organizational socialization related to positive organizational behavior, specifically looking to link with psychological capital and leadership as resources socialization, an important effort that is limited when we think about the wellbeing of the workers and the adaptation to the environment at the same time.

Within this proposal social support is considered the main source of learning and a critical factor in socialization (Allen, McManus, \& Russell, 1999; Bauer et al., 1998; Fisher, 1985; Katz, 1985; Saks \& Ashforth, 1997), because for many authors interactions newcomers and initiates represent "the primary vehicle through which initial socialization occurs" (Reichers, 1987: p. 278). Interactions between new individuals with the most experienced provide emotional support, advice and assistance (Baker \& Dutton, 2007; Taormina, 1994, 1997, 2004; Taormina \& Gao, 2005), which can promote strengths in individuals and generate wellbeing states. It is likely that the tendency to be supportive behaviors fueled by beliefs and models rooted in culture (George, 1991; LePine, Erez, \& Johnson, 2002; O’Reilly \& Chatman, 1986).

Cultures that show orientations towards flexibility, innovation and social support could influence the wellbeing of employees, increasing their personal confidence, openness to change, their orientation to their own development and their ability to respond (Van Muijen et al., 1999; Henri, 2006). Even, it is possible that many people today are increasingly interested in working in companies that have this type of flexible cultures, aimed at social support, employee development and openness to innovation as sources of adaptation and competitiveness (Taormina \& Gao, 2005; Wallach, 1983; Lund, 2003; McKinnon, Harrison, Chow, \& Wu, 2003; Silverthorne, 2004); These cultural characteristics, in general, are results of socialization that are supported by the modeling of behaviors and the own influence of the leaders (Saks \& Ashforth, 1997; Taormina, 2008).

\section{Authentic Leadership}

Leadership has been studied for several decades and has a long amount of relationships with organizational performance and wellbeing of workers. It has been approached, well as a feature, which shows the ability to influence based on the charisma and motivation to make the followers get to act beyond their own expectations of work generating a high performance (Gil, Alcover, Rico, \& Sánchez-Manzanares, 2011); or, as the process of influencing others to understand and agree on what should also facilitate and make collective efforts to achieve shared goals (Yukl, 2009) done.

One of the most important concerns for businesses today is to ensure that 
leadership reflects both the expected results and strategy to maintain an appropriate organizational climate (Yukl \& Tracey, 1992). The different theories and findings have led to classify leadership in distinctive styles; these have been presented in the organizations and have been described according to the leader's knowledge, experience and context. Some of the most mentioned are the style: a) focused on relationships, b) transactional and c) transformational (Bass \& Avolio, 1990; Hater \& Bass, 1988).

For some years, due to a combination of organizational needs, loss of credibility of models focused on individual capacity and the increase in the speed of socio-technological changes, management models based on the authenticity of values have been formulated, Organizational culture, transparency in business and environmental sustainability, giving rise to concepts such as authentic leadership (Judge \& Piccolo, 2004; O’Reilly, Caldwell, Chatman, Lapiz, \& Self, 2010; Stewart \& Johnson, 2009).

Authentic leadership is understood as the vocation that some people have to serve and be useful to others through their status and the privileged role they have in the organization. The true leader is defined as an individual who is keenly aware of their values and beliefs, their strengths and weaknesses, how you drive and how others perceive him. Due to this, this type of individuals could be more interested in the people who collaborate with them develop their skills and acquire greater autonomy in the performance of their role, instead of directing them only with their authority (Shamir \& Eilam, 2005). These two results sought by authentic leadership are also characteristics of people who have positive mental health (Pando-Moreno \& Salazar-Estrada, 2007).

Avolio and Gardner (2005) define it as a behavior pattern in which the leader seeks to be transparent and ethical when he exchanges information necessary to make decisions in relation to the members of his team; for this it is assumed that these leaders are highly aware of themselves and others, are highly aware of the context in which they operate, safe, optimistic, resilient and with a high moral character.

The authentic leadership style is formed by four dimensions that are: a) Transparency in relationships, which means that these leaders present themselves authentically when they are in situations in which they must share information and feelings in an open manner, or also to adapt to situations in which they participate appropriately; b) internalized morality, which refers to the leader using internal moral norms as a guide to self-regulate their behavior, and not economic or power interests; c) balanced processing, which describes people who objectively analyze the data of situations and people to make decisions, even if they are adverse to their way of thinking; and finally; d) self-awareness, which means that they have high levels of knowledge of their own strengths and weaknesses, as well as their followers; It is also said that they are highly aware of the way in which their own behavior influences their work team.

The four essential elements proposed by Walumbwa et al. (2008) for authentic 
leadership emerge from previous research conducted even before the formal proposal of this style of leadership.

\section{The consciousness of oneself}

This is a skill that the individual uses to recognize the emotions and consequences of their actions. It is described by Kernis (2003) as a feature of authenticity, an awareness and confidence in the goals, feelings, desires, and self-cognitions Relevant It involves being aware of the strengths and weaknesses you have and understanding of emotions and personality of oneself (Ilies, Morgeson, \& Nahrgang, 2005). It is a process in which the individual reflects their unique values and helps them to resist the social and situational demands that commit them (Luthans, Norman, \& Hughes, 2006).

\section{The internalized moral}

As part of the model of authentic leadership, refers to an internalized and integrated self-regulation is guided by internal norms and values that are in front of a group, organization or social pressures, this translates into decision-making from the internalized values (Gardner, Avolio, Luthans, May, \& Walumbwa, 2005). This moral component within the authentic leadership describes a process of making ethical and transparent decisions based on moral capacity, effectiveness, value and resistance to address ethical issues and achieve real and sustained moral actions (May et al., 2003).

\section{The balanced processing of information}

The third factor refers to the abilities that the leader possesses which make them objective and analytical about the information they acquire, and based on that, they make a decision. In addition, they are able to listen to points of view different from their own (Avolio \& Gardner, 2005). Meanwhile, Kernis (2003) defines how people with low self-esteem or weak, are motivated to select or interpret information. This allows the leader to avoid biasing the information based on their perceptions due to self-defense, self-exaltation or self-protection. The processing described balanced by Ilies, Frederick, \& Nahrgang (2005) is the basis of personal integrity.

\section{Transparency in relationships}

Within the model of authentic leadership, transparency in relations concerns appear authentic to others, this behavior promotes trust by having the openness to share information and personal expressions of thought and feelings (Kernis, 2003). As a result, followers can connect with the values, beliefs, goals and activities of the leader over time, and create a realistic social relationship that arises from the high levels of personal and social identification of the followers (Avolio, Gardner, Walumbwa, Luthans, \& May, 2004).

As transparently transmit their attributes, values, aspirations and weaknesses followers and encourage them to do the same, the basis for trust and intimacy (Avolio et al., 2004) are set. Trust in leadership has been identified as a crucial element in the effectiveness of leaders (Bass \& Avolio, 1990) and has been shown to be associated with important results for organizations such as belief in information, commitment, organizational civic behavior, satisfaction with leaders 
and intend to stay (Dirks \& Ferrin, 2002), more specifically, stressed the importance of confidence can mean for the development of authentic leadership (Avolio et al., 2004).

Several studies have explored the relationship of authentic leadership and other organizational variables, such as the commitment of followers with the leader (Leroy, Palanski, \& Simons, 2012), participation in work (Walumbwa, Wang, Wang, Schaubroeck, \& Avolio, 2010) and subsequent work satisfaction product positive and supportive relationships (Bamford, Wong, \& Laschinger, 2013).

Authentic leadership relationships have been established with loyalty to the leader; with the characteristics of the followers, the cohesion of work teams and flexible and innovative organizational cultures (Monzani, Ripoll, \& Peiró, 2014), however, Bauer and Green (1998) found that The behavior of the manager can also influence in clarifying the rules, increasing the performance, and the feelings of acceptance in the new members or when there are changes in the organization.

Kammeyer-Mueller and Wanberg (2003) found that the influence of the leader could play a key role in the socialization and adaptation, helping newcomers to develop personal resources, such as self-efficacy through modeling behavior, positive feedback and influence to generate social support and autonomy in tasks, which is typical of the authentic leadership model (Norman, Luthans, \& Luthans, 2005).

Leaders can help newcomers or members of their teams to set realistic goals and develop strategies to achieve them, helping them to focus on improving their skills and problem-solving skills, which could empower them to make decisions about work; All of them are factors related to personal strengths and efficacy beliefs that could generate a strong work identity with autonomy and dedication to their tasks.

A leadership effect related to social support in the form of tutoring is that this type of behavior is imitated and facilitates positive results between protected, improving their opportunities for promotion or generating confidence to advance their careers (Allen, Eby, Poteet, Lentz, \& Lima, 2004; Underhill, 2006).

Leadership, in conclusion, when expressed positively and oriented to ethical behavior, could be linked to results that generate an increase in the resources of individuals in the organization, to aspects of well-being close to positive mental health, and especially states autonomy and strengthening personal identity at work, which are contrary to alienation and could demonstrate optimal performance (Luthans, Avolio, Avey, \& Norman, 2007; Luthans, Avey, Avolio, Norman, \& Combs, 2006).

\section{Positive Mental Health and Wellbeing}

When observing the declaration of Ottawa of 1986 of the WHO, the positive tone is noticed when mentioning that the health must be understood like a complete state of physical, mental and social well-being and not only the absence of 
disease or handicap. Health must be understood and taken advantage of as a resource of daily life, not a vital purpose in itself; it must be emphasized social, personal resources and physical abilities of people (WHO, 1986; Ottawa Charter for Health Promotion).

Psychology studied mental health traditionally approaching it as a deficiency states or poorly associated operation pain and suffering (Vázquez, Hervas, Rahona, \& Gomez, 2009), and omitting investigate exceptions, development potential and states positive in the individual. Even today, there are few theoretical models that approach the positive approach against the enormous repertoire of psychopathological studies, which for many is still synonymous with mental health.

From the so-called positive outlook, mental health is defined as a state of optimal functioning of the individual and, therefore, focuses on promoting and facilitating the potential development of human strengths (Jahoda, 1958; Lluch, 1999, 2002; Pando-Moreno \& Salazar-Estrada, 2007). And although critics of this approach (Vázquez, 2013) refer to it as utopian, it is certainly aspirational for the development of science and wellbeing of people.

Thanks to the wide variety of approaches that have been made on mental health, it has been possible that in the field of work it is granted greater importance. But as in other fields, the negative focus, focused on the study of stress and illness, has predominated and the positive approach in the occupational field is still under development (Pando, Aranda, Salazar, \& Bermúdez, 2006; Pando, 2012).

Mental health view positively can perceive in humans a number of potential developments, the presence or absence does not indicate any psychopathology, but a quality of mental health in the individual (Pando, 2012; Pando, Franco, \& Saraz, 2006).

Any definition to be social interaction could be subject to a particular social framework, i.e. a historical relativity that we must conceive alien to ideologies, ethnocentrism and universal dogmas. When talking about the organization, none of the definitions mentioned consider the power relations that are essential in organizations and the basis of organizational behavior, generating subordination and as a subsequent effect of the conflict (Hall, 1996). These relationships give complexity to the study of mental health, leading to think of unequal relationships such as when a person is oppressed or exploited and could mean the inability to know if an individual is in an SMP state or simply is not possible perceive it or mention it.

Mainly we know that the SMP is related to the concepts of well-being and when determining its ontological character, it can be established that the disease is not the opposite of health, but alienation. Alienation in work as the opposite of SMP can be perceived because work is seen as alien to the individual and its nature, which leads to a devaluation of it, unlike other states such as psychological capital or engagement where Individuals still under a stress state are strongly linked socially and absorbed in their work. 


\section{Positive Mental Health at Work}

In today's world of work, being healthy or having health can have several ways of being defined. For some authors, in the current economic system a sick subject is one who cannot produce, thus health is often assumed as the ability to work (Rossi, 2005). The work can be considered exhausting and generator discomfort or even the most enjoyable part of life, when the work absorbs us completely, and we do it, enjoying it, effortlessly, as in flow statements and work engagement (Bakker, Schaufeli, Leiter, \& Taris, 2008; Nakamura \& Csikszentmihalyi, 2014).

To Pando, Franco, \& Saraz (2006) the work itself no ill to anyone, are the conditions of work that they can become the agent of disease or wellbeing. Thinking about working life should not be limited to the fact of not suffering accidents or occupational diseases at the end of our workday, the organization of work can create feelings of self-confidence, raise self-esteem in the worker, improve social support networks labor and extra-work, increase satisfaction, and other positive indicators of mental health.

Positive mental health at work has been explored and conceptualized in diverse ways and in most of them the emphasis is observed on the fact that it is a result of the interaction between the individual capacities, the perceptions of mastery and control and the real environmental demands (Moreno, Cortés, Baltazar, Rodríguez, \& Rodríguez, 2015; Lluch, 1999, 2002; Rossi, 2005).

Among the different approaches, it is the focus of Eugenics Labor proposed by Pando, Franco, \& Saraz, 2006; Pando, Aranda, Parra, \& Ruiz, 2013, on which a configuration for positive mental health at work consists of components such as self-esteem, social support, work engagement, locus of control, life project, creativity, optimism, perseverance, social awareness, pleasure is proposed, ability to transform reality, ability to give and receive affection, among others.

When talking about the concept of mental health within the scope of work, we can affirm that it is a social or individual practice that represents the transformation capacity of reality that a person has. This does not imply that the state is permanent or immutable, but depends on various factors such as awareness and the role played in a given organization.

From this model appears the theoretical construct of Positive Occupational Mental Health that includes six factors considered positive occupational mental health such as personal well-being at work, positive interpersonal relationships in the workplace, immersion in the task, empowerment in the work, the philosophy of working life, and personal strengths at work. When addressing them, the authors mention that they could be found simultaneously in the individual in cognitive, socio-emotional, behavioral and spiritual dimensions (Vázquez-Colunga, Pando-Moreno, Colunga-Rodríguez, Preciado-Serrano, Orozco-Solís, Ángel-González, \& Vázquez-Juárez, 2017).

Each dimension refers to aspects related to its content, and which make its evaluation and observation possible. For example, the cognitive dimension contains thoughts, beliefs, ideas and value judgments; behavioral refers to behaviors, 
actions, practices and attitudes; the socioaffective be operationalized by feelings, emotions, motivation and intra and interpersonal relationships; finally have a meaning and give meaning to work or find in it a source of pride, contribution to the community and general aspects of self-realization, referring to the spiritual dimension.

The six factors SMPO be understood from the following Table 1, where its conceptual and operational definition is shown.

Organizational culture and leadership can work to explain the process of occupational positive mental health, but it is the process of organizational socialization which is closer empirically explaining this state of mental health, mainly because socialization has as its effects the integration of an individual to the culture of the organization, facilitates understanding of the rules and regulations of this complex environment, learning the role and ability of workers to be motivated by improving perceptions of themselves and their sense of wellbeing in general (Pando et al., 2006; Lluch, 2002; Ryff, 1989; Avey, Luthans, Smith, \& Palmer, 2010).

The importance of emphasizing the positive states to psychological or mental level is that not only are part of health comprehensively speaking, but that may influence disease onset and recovery processes (Fredrickson, 2000; Kok, Coffey, Cohn, Catalino, Vacharkulksemsuk, Algoe, \& Fredrickson, 2013).

The perception of healthy people who are probably marked by a positive sense of self, of self confidence in their own abilities to have dominion over the environment, an optimistic vision of the future and a social environment nurtured

T able 1. Prepared from the original Vázquez-Colunga (2017).

\begin{tabular}{|c|c|c|}
\hline Aspect of the SMPO & conceptual definition & operational definition \\
\hline $\begin{array}{l}\text { positive interpersonal } \\
\text { relationships at work }\end{array}$ & $\begin{array}{l}\text { It refers to an individual's ability to establish } \\
\text { healthy and loving relationships with others at } \\
\text { work. }\end{array}$ & $\begin{array}{l}\text { Caring labor relations, groupality, social support networks, sense } \\
\text { of belonging to occupational group, satisfactory adherence to } \\
\text { labor standards, assertive communication at work. }\end{array}$ \\
\hline $\begin{array}{l}\text { Personal Wellbeing at } \\
\text { Work }\end{array}$ & $\begin{array}{l}\text { It refers to the assessment of the individual in } \\
\text { relation to his work in positive terms, and that } \\
\text { affects the presence of feelings, sensations and } \\
\text { positive emotions in their work. }\end{array}$ & $\begin{array}{l}\text { Positive self-worth as a worker, positive self-esteem at work, } \\
\text { enjoy gender identity at work, vitality at work, positive affectivity } \\
\text { derived from work, enjoyment of work, sense of achievement at } \\
\text { work, self-fulfillment at work. }\end{array}$ \\
\hline $\begin{array}{l}\text { Empowerment at } \\
\text { Work }\end{array}$ & $\begin{array}{l}\text { It refers to the individual's capabilities needed } \\
\text { to improve their own working life as well as the } \\
\text { process by which people develop these skills. }\end{array}$ & $\begin{array}{l}\text { Adequate perception of the reality of work, self-regulation at } \\
\text { work, self-determination for work, labor self-efficacy, internal } \\
\text { locus of control in the workplace scenario, adaptation to the } \\
\text { workplace, domination and control of the occupational setting, } \\
\text { self-actualization and career development, self-management of } \\
\text { health occupational. }\end{array}$ \\
\hline $\begin{array}{l}\text { Philosophy of } \\
\text { working life }\end{array}$ & $\begin{array}{l}\text { It refers to the set of thoughts, beliefs and } \\
\text { values that help individuals make sense of their } \\
\text { working lives and lead a healthy, pleasurable } \\
\text { and meaningful way. }\end{array}$ & $\begin{array}{l}\text { Sense and meaning of work, labor ideals, project work life } \\
\text { balance work-leisure time, occupational identity, congruence of } \\
\text { personal values-work. }\end{array}$ \\
\hline $\begin{array}{l}\text { Personal strengths at } \\
\text { work }\end{array}$ & $\begin{array}{l}\text { It refers to a set of positive features present in } \\
\text { the individual which promote human potential } \\
\text { and help having a satisfactory working life and } \\
\text { significant. }\end{array}$ & $\begin{array}{l}\text { Conservation of job autonomy, creativity at work, hope at work, } \\
\text { optimism at work, altruism at work, serenity and harmony at } \\
\text { work, sense of humor at work, a sense of transcendence through. }\end{array}$ \\
\hline
\end{tabular}


meaningful relationships mean a support that allow individuals face the daily difficulties and be a reserve when people have to solve problems or stressful even have to do with the existence.

Even the wellbeing state is important because it will encourage people to develop better psychological, social and communally (Fredrickson, 2013) by developing skills such as staying optimistic, be resilient or give meaning to adversity as we know are precursors physical health (Rossi, 2005).

\section{SMPO Model Based on Leadership and Resources Socialization}

In order to create an explanatory model of Mental Health is positive organizational resources necessary to incorporate background that could be strongly linked to positive mental health. To better explain our model, we have divided into three successive stages or steps that demonstrate the nature of this model based on strengths and authentic, successive and focused on positive mental health leadership.

First stage:

Authentic Leadership generating positive relationships and empowerment at work.

First, the model of authentic leadership (see Figure 1) is proposed, which the observables such behavioral and relational transparency, balanced processing, influence being a history of positive interpersonal relationships, developing emotional attachment between workers and generate loyalty between them, so much as it explains the model of organizational commitment (Meyer \& Allen, 1984; Meyer, Allen, \& Topolnytsky, 1998). Probably when workers perceive that a leader behaves taking giving importance of all opinions of team members and displayed transparent in their dealings, enables trusted relationships and modeling based on the same support are developed.

Well balanced processing could be influencing socialization through increasing peer support as in the case of positive interpersonal relationships, causing new or processes workers adaptation get emotional and instrumental support from their peers because their supervisors consider all opinions and refer to them by recognizing as mentioned Filstad (2004, 2011). The instrumental and emotional support among its relationships adoption clarification of the role and thanks to the self-confidence and self-regulation shown in the role, or empowerment at work on the model of SMPO.

\section{Prospects to develop personal strengths at work.}

Future prospects is a variable of the process of socialization and adaptation to organizational culture, which occurs when a person has managed to understand how it works the organization and get promotions or obtain greater economic benefits which can enable it decides and be able to develop their personal strengths increasing their productivity at work and improving valuations of himself being considered valuable for its average organizational partner. 


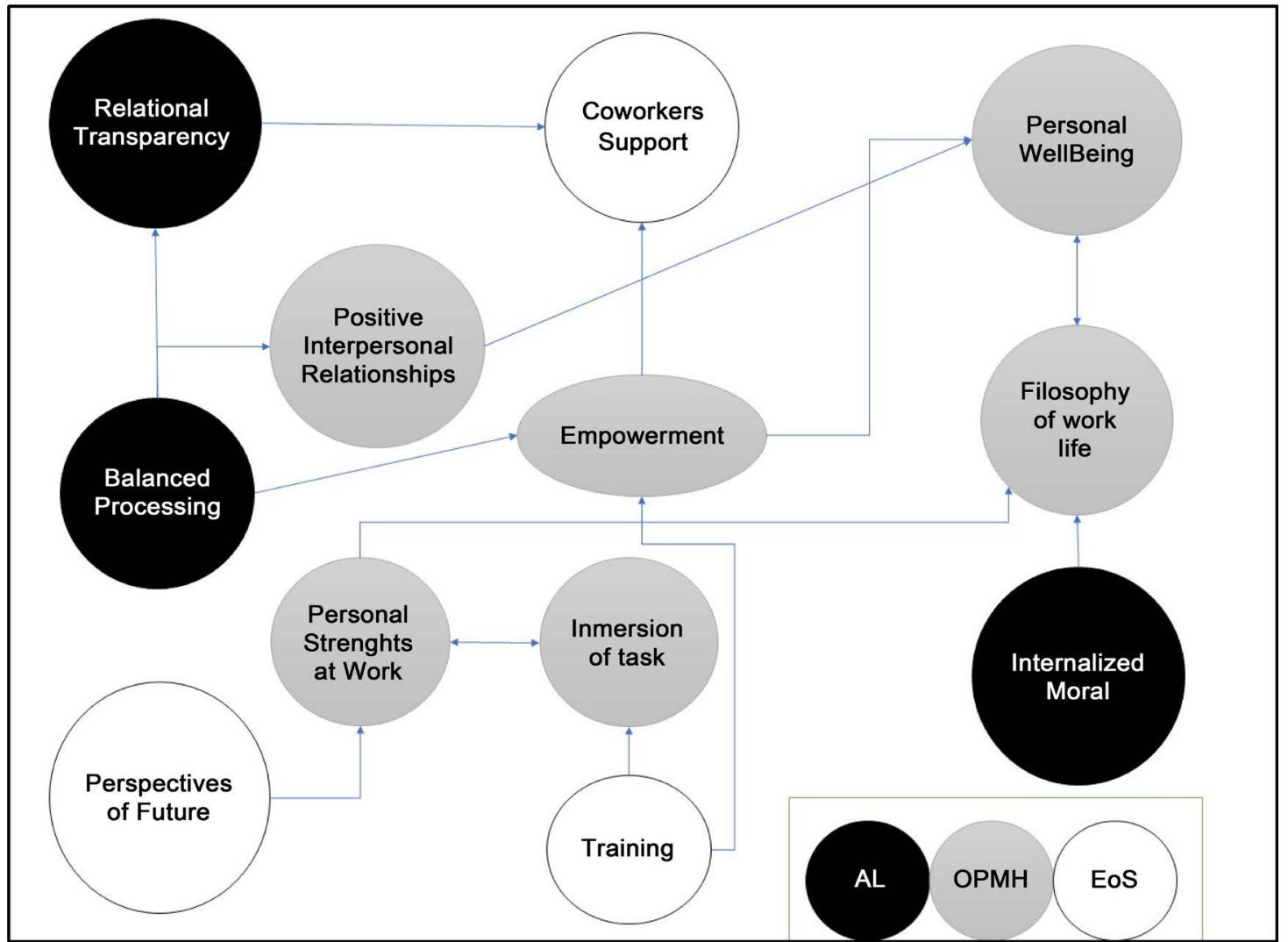

Figure 1. Positive Mental Health Model based on Authentic Leadership and Elements of Socialization. Own elaboration. Calderón-Mafud, Pando-Moreno, Colunga-Rodríguez, \& Preciado Serrano, 2018.

Personal strengths in turn may be interacting each other with immersion in the task (possibility of generating dedication and absorption in tasks) because these in turn generate success in productive tasks because of the training received by persons increases stages start and when technological or organizational changes in enterprises.

Second stage:

Empowerment at work and positive relations as antecedents Wellbeing at Work.

Labor wellbeing characterized by valuations and positive self-esteem that generate enjoyment and feelings of accomplishment and self-fulfillment at work, can come in this model of empowerment and positive interpersonal relation-ships achieved at work thanks to the support of coworkers and balanced processing from the leaders. This facilitates well-being comes from the chances of having healthy and lasting relationships within the work, outside alienation at work, as well as the sense of mastery and beliefs of self-confidence that improve the regulation of workers, also improving its response stress.

Third stage:

Personal strengths and wellbeing at work as a history of the philosophy of working life.

Perma model (Slavin, Schindler, Chibnall, Fendell, \& Shoss, 2012), a life full of 
meaning might be closer to a full and healthy life, however, is based on difficult aspects of getting (remove unnecessary stressors, or more either related to organizational development techniques applied for decades (think tanks and innovation).

In this model, we propose that the philosophy of working life (characterized because someone gives you a sense and meaning of work, managed to develop ideal and a draft working life, to give you a consistent occupational identity with their values and personal life) is developed as a result of personal well-being at work, self-development strengths and the effect of internalized moral congruent leaders, who guided by personal moral standards rather than economic interests or power, they allow workers to develop an identity, without trying to alienate their own goals or even preventing it to their partners.

\section{Conclusion}

Common criticisms of the positive approach to psychology that have been justified often find proposals centered on a "happiology" baseless and more philosophical than empirical. In this paper, we used the organizational socialization and authentic leadership to show an organizational approach to research and practice of occupational positive mental health. Addressing the SMPO from this point of view may complement and remove a natural bias workplace and business: the issue of mental health is omitted or under the approach circumvents productivity.

Moreover, the approach we have described in this article provides a wider variety of directions to develop positive mental health at work and integrates studies of socialization and leadership with a broad view of the wellbeing of workers.

In this approach, we have integrated research and literature on SMPO, the resource model and tasks, and the role of leadership as a factor of organizational socialization.

To approach it in this way, we suggest a new set of results to consider when involving socialization and the role of leader, e.g. factors self-regulation, ethical conduct and balanced processing, are relevant to research and practice, since it comes from widely studied fields that can be validated in an outcome related to wellbeing.

On the other hand, this approach incorporates resources of the organization to function in a balanced way with the mental health of workers (training processes, social support, prospects) into a coherent framework and linking factors authentic leadership valuing effects of leadership learning models to be valuable in terms of the vicar to extend forms of relationship and behavioral reinforcement entire organizational culture.

Finally, this model proposes that positive mental health is not an integral state or factored, but a process of individual development in which psychosocial factors influence the individual and generate behaviors, beliefs and learning that 
end in wellbeing states that in the long term facilitate the generation of a personal philosophy of life at work taken of the model leaders.

\section{References}

Allen, D. G. (2006). Do Organizational Socialization Tactics Influence Newcomer Embeddedness and Turnover? Journal of Management, 32, 237-256. https://doi.org/10.1177/0149206305280103

Allen, N. J., \& Meyer, J. P. (1990). The Measurement and Antecedents of Affective, Continuance and Normative Commitment to the Organization. Journal of Occupational and Organizational Psychology, 63, 1-18. https://doi.org/10.1111/j.2044-8325.1990.tb00506.x

Allen, T. D., Eby, L. T., Poteet, M. L., Lentz, E., \& Lima, L. (2004). Career Benefits Associated with Mentoring for Protégés: A Meta-Analysis. Journal of Applied Psychology, 89, 127-136.

Allen, T. D., McManus, S. E., \& Russell, J. E. (1999). Newcomer Socialization and Stress: Formal Peer Relationships as a Source of Support. Journal of Vocational Behavior, 54, 453-470. https://doi.org/10.1006/jvbe.1998.1674

Aranda-Beltrán, C., Pando-Moreno, M., Torres-López, T., Salazar-Estrada, J., \& Franco-Chávez, S. (2005). Factores psicosociales y síndrome de burnout en médicos de familia. México. Anales de la Facultad de Medicina, 66, 225-231.

http://www.scielo.org.pe/scielo.php?script=sci_arttext\&pid=S1025-55832005000300006 \&lng=es\&tlng=es

Ashforth, B. E., Sluss, D. M., \& Harrison, S. H. (2007). Socialization in Organizational Contexts. In G. P. Hodgkinson, \& J. K. Ford (Eds.), International Review of Industrial and Organizational Psychology (Vol. 22, pp. 1-70). Hoboken, NJ: John Wiley \& Sons Ltd.

Avey, J. B., Luthans, F., Smith, R. M., \& Palmer, N. F. (2010). Impact of Positive Psychological Capital on Employee Well-Being over Time. Journal of Occupational Health Psychology, 15, 17-28. https://doi.org/10.1037/a0016998

Avolio, B. J., \& Gardner, W. L. (2005). Authentic Leadership Development: Getting to the Root of Positive Forms of Leadership. The Leadership Quarterly, 16, 315-338. https://doi.org/10.1016/j.leaqua.2005.03.001

Avolio, B. J., Gardner, W. L., Walumbwa, F. O., Luthans, F., \& May, D. R. (2004). Unlocking the Mask: A Look at the Process by Which Authentic Leaders Impact Follower Attitudes and Behaviors. The Leadership Quarterly, 15, 801-823. https://doi.org/10.1016/j.leaqua.2004.09.003

Baker, W., \& Dutton, J. E. (2007). Enabling Positive Social Capital in Organizations. In J. E. Dutton, \& B. Ragins (Eds.), Exploring Positive Relationships at Work: Building a Theoretical and Research Foundation (pp. 325-346). Mahwah, NJ: Lawrence Erlbaum.

Bakker, A. B., \& Demerouti, E. (2007). The Job Demands-Resources Model: State of the Art. Journal of Managerial Psychology, 22, 309-328. https://doi.org/10.1108/02683940710733115

Bakker, A. B., \& Demerouti, E. (2013). La teoría de las demandas y los recursos laborales. Revista de Psicología del Trabajo y de las Organizaciones, 29, 107-115. https://doi.org/10.5093/tr2013a16

Bakker, A. B., Schaufeli, W. B., Leiter, M. P., \& Taris, T. W. (2008). Work Engagement: An Emerging Concept in Occupational Health Psychology. Work \& Stress, 22, 187-200. https://doi.org/10.1080/02678370802393649 
Bamford, M., Wong, C. A., \& Laschinger, H. (2013). The Influence of Authentic Leadership and Areas of Worklife on Work Engagement of Registered Nurses. Journal of Nursing Management, 21, 529-540. https://doi.org/10.1111/j.1365-2834.2012.01399.x

Bass, B. M., \& Avolio, B. J. (1990). Transformational Leadership Development: Manual for the Multifactor Leadership Questionnaire. California: Consulting Psychologists Press.

Bauer, T. N., \& Green, S. G. (1998). Testing the Combined Effects of Newcomer Information Seeking and Manager Behavior on Socialization. Journal of Applied Psychology, 83, 72-83. https://doi.org/10.1037/0021-9010.83.1.72

Bauer, T. N., Morrison, E. W., \& Callister, R. R. (1998). Organizational Socialization: A Review and Directions for Future Research. In G. R. Ferris (Ed.), Research in Personnel and Human Resource Management (Vol. 16, pp. 149-214). Samford, CT: JAI Press.

Calderón-Mafud, J. L., Pando-Moreno, M., Colunga-Rodríguez, C., Preciado Serrano, M. L. (2018). Model of Positive Mental Health Based on Authentic Leadership and Elements of Socialization. Own Elaboration.

Chao, G. T., O’Leary-Kelly, A. M., Wolf, S., Klein, H. J., \& Gardner, P. D. (1994). Organizational Socialization: Its Content and Consequences. Journal of Applied Psychology, 79, 730-743. https://doi.org/10.1037/0021-9010.79.5.730

Cooper-Thomas, H. D., \& Anderson, N. (2006). Organizational Socialization: A New Theoretical Model and Recommendations for Future Research and HRM Practices in Organizations. Journal of Managerial Psychology, 21, 492-516.

https://doi.org/10.1108/02683940610673997

Demerouti, E., Bakker, A. B., Nachreiner, F., \& Schaufeli, W. B. (2001). The Job Demands-Resources Model of Burnout. Journal of Applied Psychology, 86, 499-512. https://doi.org/10.1037/0021-9010.86.3.499

Dirks, K. T., \& Ferrin, D. L. (2002). Trust in Leadership: Meta-Analytic Findings and Implications for Research and Practice. Journal of Applied Psychology, 87, 611-628. https://doi.org/10.1037/0021-9010.87.4.611

Filstad, C. (2004). How Newcomers Use Role Models in Organizational Socialization. Journal of Workplace Learning, 16, 396-409. https://doi.org/10.1108/13665620410558297

Filstad, C. (2011). Organizational Commitment through Organizational Socialization Tactics. Journal of Workplace Learning, 23, 376-390. https://doi.org/10.1108/13665621111154395

Fisher, C. D. (1985). Social Support and Adjustment to Work: A Longitudinal Study. Journal of Management, 11, 39-53. https://doi.org/10.1177/014920638501100304

Fredrickson, B. L. (2000). Cultivating Positive Emotions to Optimize Health and Well-Being. Prevention \& Treatment, 3, Article 1. https://doi.org/10.1037/1522-3736.3.1.31a

Fredrickson, B. L. (2013). Positive Emotions Broaden and Build. In J. M. Olson (Ed.), Advances in Experimental Social Psychology (Vol. 47, pp. 1-53). Amsterdam: Elsevier. https://doi.org/10.1016/B978-0-12-407236-7.00001-2

Gardner, W. L., Avolio, B. J., Luthans, F., May, D. R., \& Walumbwa, F. (2005). "Can You See the Real Me?” A Self-Based Model of Authentic Leader and Follower Development. The Leadership Quarterly, 16, 343-372. https://doi.org/10.1016/j.leaqua.2005.03.003

George, J. M. (1991). State or Trait: Effects of Positive Mood on Prosocial Behaviors at Work. Journal of Applied Psychology, 76, 299-307.

https://doi.org/10.1037/0021-9010.76.2.299 
Gil, F., Alcover, C., Rico, R., \& Sánchez-Manzanares, M. (2011). Nuevas formas de liderazgo en equipos de trabajo. Papeles del Psicólogo, 32, 38-47.

Hall, R. H. (1996). Estructuras, procesos y resultados. México: PHI.

Hater, J. J., \& Bass, B. M. (1988). Superiors' Evaluations and Subordinates' Perceptions of Transformational and Transactional Leadership. Journal of Applied Psychology, 73, 695-702. https://doi.org/10.1037/0021-9010.73.4.695

Haueter, J. A., Macan, T. H., \& Winter, J. (2003). Measurement of Newcomer Socialization: Construct Validation of a Multidimensional Scale. Journal of Vocational Behavior, 63, 20-39. https://doi.org/10.1016/S0001-8791(02)00017-9

Henri, J. F. (2006). Organizational Culture and Performance Measurement Systems. Accounting, Organizations and Society, 31, 77-103. https://doi.org/10.1016/j.aos.2004.10.003

Ilies, R., Morgeson, F. P., \& Nahrgang, J. D. (2005). Authentic Leadership and Eudaemonic Well-Being: Understanding Leader-Follower Outcomes. The Leadership Quarterly, 16, 373-394. https://doi.org/10.1016/j.leaqua.2005.03.002

Jahoda, M. (1958). Current Concepts of Positive Mental Health. New York: Basic Books, Inc.

Judge, T. A., \& Piccolo, R. F. (2004). Transformational and Transactional Leadership: A Meta-Analytic Test of Their Relative Validity. Journal of Applied Psychology, 89, 755-768. https://doi.org/10.1037/0021-9010.89.5.755

Kammeyer-Mueller, J. D., \& Wanberg, C. R. (2003). Unwrapping the Organizational Entry Process: Disentangling Multiple Antecedents and Their Pathways to Adjustment. Journal of Applied Psychology, 88, 779-794. https://doi.org/10.1037/0021-9010.88.5.779

Katz, R. (1985). Organizational Stress and Early Socialization Experiences. Cambridge, MA: Massachusetts Institute of Technology.

Kernis, M. H. (2003). Toward a Conceptualization of Optimal Self-Esteem. Psychological Inquiry, 14, 1-26. https://doi.org/10.1207/S15327965PLI1401_01

Kok, B. E., Coffey, K. A., Cohn, M. A., Catalino, L. I., Vacharkulksemsuk, T., Algoe, S. B. et al. (2013). How Positive Emotions Build Physical Health: Perceived Positive Social Connections Account for the Upward Spiral between Positive Emotions and Vagal Tone. Psychological Science, 24, 1123-1132. https://doi.org/10.1177/0956797612470827

LePine, J. A., Erez, A., \& Johnson, D. E. (2002). The Nature and Dimensionality of Organizational Citizenship Behavior: A Critical Review and Meta-Analysis. Journal of Applied Psychology, 87, 52-65.

Leroy, H., Palanski, M. E., \& Simons, T. (2012). Authentic Leadership and Behavioral Integrity as Drivers of Follower Commitment and Performance. Journal of Business Ethics, 107, 255-264. https://doi.org/10.1007/s10551-011-1036-1

Lluch, M. T. (1999). Construcción de una escala para medir la salud mental positiva. Barcelona: Universidad de Barcelona.

Lluch, M. T. (2002). Evaluación empírica de un modelo conceptual de salud mental positiva. Salud Mental, 25, 42-55.

Louis, M. R. (1980). Surprise and Sense Making: What Newcomers Experience in Entering Unfamiliar Organizational Settings. Administrative Science Quarterly, 25, 226-251. https://doi.org/10.2307/2392453

Lund, D. B. (2003). Organizational Culture and Job Satisfaction. Journal of Business \& Industrial Marketing, 18, 219-236. https://doi.org/10.1108/0885862031047313

Luthans, F., Avey, J. B., Avolio, B. J., Norman, S. M., \& Combs, G. M. (2006). Psychologi- 
cal Capital Development: Toward a Micro-Intervention. Journal of Organizational Behavior, 27, 387-393. https://doi.org/10.1002/job.373

Luthans, F., Avolio, B. J., Avey, J. B., \& Norman, S. M. (2007). Positive Psychological Capital: Measurement and Relationship with Performance and Satisfaction. Personnel Psychology, 60, 541-572. https://doi.org/10.1111/j.1744-6570.2007.00083.x

Luthans, F., Norman, S., \& Hughes, L. (2006). Authentic Leadership. In R. Burke, \& C. Cooper (Eds.), Inspiring Leaders (pp. 84-104). London: Routledge, Taylor \& Francis.

May, D. R., Chan, A. Y., Hodges, T. D., \& Avolio, B. J. (2003). Developing the Moral Component of Authentic Leadership. Organizationaldynamics, 32, 247-260. https://doi.org/10.1016/S0090-2616(03)00032-9

McKinnon, J. L., Harrison, G. L., Chow, C. W., \& Wu, A. (2003). Organizational Culture: Association with Commitment, Job Satisfaction, Propensity to Remain, and Information Sharing in Taiwan. International Journal of Business Studies, 11, 25-44.

Meyer, J. P., \& Allen, N. J. (1984). Testing the "Side-Bet Theory" of Organizational Commitment: Some Methodological Considerations. Journal of Applied Psychology, 69, 372-378. https://doi.org/10.1037/0021-9010.69.3.372

Meyer, J. P., Allen, N. J., \& Topolnytsky, L. (1998). Commitment in a Changing World of Work. Canadian Psychology/Psychologie Canadienne, 39, 83-93. https://doi.org/10.1037/h0086797

Michaels, R. E., Cron, W. L., Dubinsky, A. J., \& Joachimsthaler, E. A. (1988). Influence of Formalization on the Organizational Commitment and Work Alienation of Salespeople and Industrial Buyers. Journal of Marketing Research, 25, 376-383.

https://doi.org/10.2307/3172948

Monzani, L., Ripoll, P., \& Peiró, J. M. (2014). Followers' Agreeableness and Extraversion and Their Loyalty towards Authentic Leadership. Psicothema, 26, 69-75.

Moreno, M. P., Cortés, S. G. L., Baltazar, R. G., Rodríguez, M. G. A., \& Rodríguez, L. F. L. (2015). Validez y confiabilidad de la escala de salud mental positiva. Psicogente, 18, 78-88.

Nakamura, J., \& Csikszentmihalyi, M. (2014). The Concept of Flow. In Flow and the foundations of Positive Psychology (pp. 239-263). Dordrecht: Springer. https://doi.org/10.1007/978-94-017-9088-8_16

Nelson, D. L., \& Quick, J. C. (1991). Social Support and Newcomer Adjustment in Organizations: Attachment Theory at Work? Journal of Organizational Behavior, 12, 543-554. https://doi.org/10.1002/job.4030120607

Norman, S., Luthans, B., \& Luthans, K. (2005). The Proposed Contagion Effect of Hopeful Leaders on the Resiliency of Employees and Organizations. Journal of Leadership \& Organizational Studies, 12, 55-64. https://doi.org/10.1177/107179190501200205

O’Reilly, C. A., \& Chatman, J. (1986). Organizational Commitment and Psychological Attachment: The Effects of Compliance, Identification, and Internalization on Prosocial Behavior. Journal of Applied Psychology, 71, 492-499. https://doi.org/10.1037/0021-9010.71.3.492

O’Reilly, C. A., Caldwell, D. F., Chatman, J. A., Lapiz, M., \& Self, W. (2010). How Leadership Matters: The Effects of Leaders' Alignment on Strategy Implementation. The Leadership Quarterly, 21, 104-113. https://doi.org/10.1016/j.leaqua.2009.10.008

Pando, M. (2012). Salud Mental Positiva. In M. Pando et al. (Ed.), Eugenesia laboral: Salud mental positiva en el trabajo (pp. 15-30). Cali: Universidad Libre Seccional Cali.

Pando, M., Aranda, C., Parra, L., \& Ruiz, D. (2013). Eugenesia Laboral: Salud Mental Positiva en el Trabajo. Colombia: Editorial Universidad Libre Seccional Cali. 
Pando, M., Aranda, C., Salazar, J. G., \& Bermúdez, D. (2006). La salud mental positiva.

Pando, M., Franco, S. A., \& Saraz, S. (2006). Factores Psicosociales y salud mental en el trabajo. México: Editorial Universidad de Guadalajara.

Pando-Moreno, M., \& Salazar-Estrada, J. G. (2007). Calidad de vida en el trabajo y la salud mental positiva. Evaluación e intervención psicosocial (pp. 81-109). Mollet del Vallès, Barcelona: Asociación de Expertos en Psicosociología Aplicada-AEPA.

Reichers, A. E. (1987). An Interactionist Perspective on Newcomer Socialization Rates. Academy of Management Review, 12, 278-287.

Rollag, K., Parise, S., \& Cross, R. (2005). Getting New Hires Up to Speed Quickly. MIT Sloan Management Review, 46, 35-41.

Rossi, R. (2005). El hombre como ser social y la conceptualización de la salud mental positiva. Investigación en Salud, 7, 105-111.

Ryff, C. D. (1989). Happiness Is Everything, or Is It? Explorations on the Meaning of Psychological Well-Being. Journal of Personality and Social Psychology, 57, 1069-1081. https://doi.org/10.1037/0022-3514.57.6.1069

Saks, A. M. (1996). The Relationship between the Amount and Helpfulness of Entry Thaining and Work Outcomes. Human Relations, 49, 429-451. https://doi.org/10.1177/001872679604900402

Saks, A. M., \& Ashforth, B. E. (1997). Organizational Socialization: Making Sense of the Past and Present as a Prologue for the Future. Journal of Vocational Behavior, 51, 234-279. https://doi.org/10.1006/jvbe.1997.1614

Saks, A. M., \& Gruman, J. A. (2011). Organizational Socialization and Positive Organizational Behaviour: Implications for Theory, Research, and Practice. Canadian Journal of Administrative Sciences/Revue Canadienne des Sciences de l'Administration, 28, 14-26. https://doi.org/10.1002/cjas.169

Salanova, M., Agut, S., \& Peiró, J. M. (2005). Linking Organizational Resources and Work Engagement to Employee Performance and Customer Loyalty: The Mediation of Service Climate. Journal of Applied Psychology, 90, 1217-1227. https://doi.org/10.1037/0021-9010.90.6.1217

Sarros, J. C., Tanewski, G. A., Winter, R. P., Santora, J. C., \& Densten, I. L. (2002). Work Alienation and Organizational Leadership. British Journal of Management, 13, 285-304. https://doi.org/10.1111/1467-8551.00247

Shamir, B., \& Eilam, G. (2005). "What's Your Story?” A Life-Stories Approach to Authentic Leadership Development. The Leadership Quarterly, 16, 395-417. https://doi.org/10.1016/j.leaqua.2005.03.005

Silverthorne, C. (2004). The Impact of Organizational Culture and Person-Organization Fit on Organizational Commitment and Job Satisfaction in Taiwan. Leadership \& Organization Development Journal, 25, 592-599. https://doi.org/10.1108/01437730410561477

Slavin, S. J., Schindler, D., Chibnall, J. T., Fendell, G., \& Shoss, M. (2012). PERMA: A Model for Institutional Leadership and Culture Change. Academic Medicine, 87, 1481. https://doi.org/10.1097/ACM.0b013e31826c525a

Stewart, M. M., \& Johnson, O. E. (2009). Leader-Member Exchange as a Moderator of the Relationship between Work Group Diversity and Team Performance. Group \& Organization Management, 34, 507-535. https://doi.org/10.1177/1059601108331220

Taormina, G. R., \& Gao, J. (2005). Effects of Organizational Socialization on Work Enthusiasm in Two Chinese Cultures. In 65th Annual Meeting of the Academy of Management (Vol. 20, p. 26). Honolulu, USA. 
http://umir.umac.mo/jspui/bitstream/123456789/15713/1/10492_Taormina

Taormina, R. J. (1994). The Organizational Socialization Inventory. International Journal of Selection and Assessment, 2, 133-145. https://doi.org/10.1111/j.1468-2389.1994.tb00134.x

Taormina, R. J. (1997). Organizational Socialization: A Multidomain, Continuous Process Model. International Journal of Selection and Assessment, 5, 29-47. https://doi.org/10.1111/1468-2389.00043

Taormina, R. J. (2004). Convergent Validation of Two Measures of Organizational Socialization. The International Journal of Human Resource Management, 15, 76-94. https://doi.org/10.1080/0958519032000157357

Taormina, R. J. (2008). Interrelating Leadership Behaviors, Organizational Socialization, and Organizational Culture. Leadership \& Organization Development Journal, 29, 85-102. https://doi.org/10.1108/01437730810845315

Underhill, C. M. (2006). The Effectiveness of Mentoring Programs in Corporate Settings: A Meta-Analytical Review of the Literature. Journal of Vocational Behavior, 68, 292-307. https://doi.org/10.1016/j.jvb.2005.05.003

Van Muijen, J. J. et al. (1999). Organizational Culture: The Focus Questionnaire. European Journal of Work and Organizational Psychology, 8, 551-568. https://doi.org/10.1080/135943299398168

Vázquez, C. (2013). La psicología positiva y sus enemigos: Una réplica en base a la evidencia científica. Papeles del Psicólogo, 34, 91-115.

Vázquez, C., Hervás, G., Rahona, J. J., \& Gómez, D. (2009). Bienestar psicológico y salud: Aportaciones desde la Psicología Positiva. Anuario de Psicología Clínica y de la Salud, $5,15-28$.

Vázquez-Colunga, J. C. (2017). Diseño, validez y fiabilidad de un instrumento multidimensional para medir la salud mental positiva ocupacional. Doctoral Dissertation, México, DF: Centro Universitario de Ciencias de la Salud, Universidad de Guadalajara.

Vázquez-Colunga, J. C., Pando-Moreno, M., Colunga-Rodríguez, C., Preciado-Serrano, M. D. L., Orozco-Solís, M. G., Ángel-González, M., \& Vázquez-Juárez, C. L. (2017). Occupational Positive Mental Health: Proposal of a Theoretical Model for the Positive Approach of Mental Health at Work. Saúde e Sociedade, 26, 584-595. https://doi.org/10.1590/s0104-12902017169061

Wallach, E. J. (1983). Individuals and Organizations: The Cultural Match. Training \& Development Journal, 37, 28-36.

Walumbwa, F. O., Avolio, B. J., Gardner, W. L., Wernsing, T. S., \& Peterson, S. J. (2008). Authentic Leadership: Development and Validation of a Theory-Based Measure. Journal of Management, 34, 89-126. https://doi.org/10.1177/0149206307308913

Walumbwa, F. O., Wang, P., Wang, H., Schaubroeck, J., \& Avolio, B. J. (2010). Retracted: Psychological Processes Linking Authentic Leadership to Follower Behaviors. The Leadership Quarterly, 21, 901-914. https://doi.org/10.1016/j.leaqua.2010.07.015

Wanous, J. P. (1992). Organizational Entry: Recruitment, Selection, Orientation, and socialization of Newcomers. Upper Saddle River, NJ: Prentice Hall.

World Health Organization (1986). The Ottawa Charter for Health Promotion. In First International Conference on Health Promotion. Geneva: WHO.

Yukl, G. (2009). Leading Organizational Learning: Reflections on Theory and Research. The Leadership Quarterly, 20, 49-53. https://doi.org/10.1016/j.leaqua.2008.11.006 
Yukl, G., \& Tracey, J. B. (1992). Consequences of Influence Tactics Used with Subordinates, Peers, and the Boss. Journal of Applied Psychology, 77, 525-535.

https://doi.org/10.1037/0021-9010.77.4.525

Zak, P. J. (2011). The Physiology of Moral Sentiments. Journal of Economic Behavior \& Organization, 77, 53-65. https://doi.org/10.1016/j.jebo.2009.11.009

Zak, P. J. (2017). The Neuroscience of Trust. Harvard Business Review, January-February, 84-90. 